\title{
WT1-AS Gene
}

National Cancer Institute

\section{Source}

National Cancer Institute. WT1-AS Gene. NCI Thesaurus. Code C106215.

This gene may play a role in the regulation of gene expression. 